\begin{tabular}{|l|l|}
\hline $\begin{array}{l}\text { 2. To: (Receiving Organization) } \\
\text { Distribution }\end{array}$ & $\begin{array}{l}\text { 3. From: (Originating Organization) } \\
\text { RPP Ugrade }\end{array}$ \\
\hline $\begin{array}{l}\text { 5. Proj./Prog./Dept./Div.: } \\
\text { Core Sampling }\end{array}$ & $\begin{array}{l}\text { 6. Design Authority/Design Agent/Cog. Engr.: } \\
\text { Rob Dale }\end{array}$ \\
\hline
\end{tabular}

8. Originator Remarks:

Development of the Forked Release Disk Pintle Connection

4. Related EDT No.:

N.A.

7. Purchase Order No:

N.A.

9. Equip./Component No.:

N.A.

10. System/Bldg./Facility:

$200 \mathrm{G}$

12. Major Assm. Dwg. No.:

$\mathrm{H}-2-690140$

11. Receiver Remarks: 11A. Design Baseline Document? $O$ Yes $O$ No
13. Permit/Permit Application No.:

N.A.

14. Required Response Date:

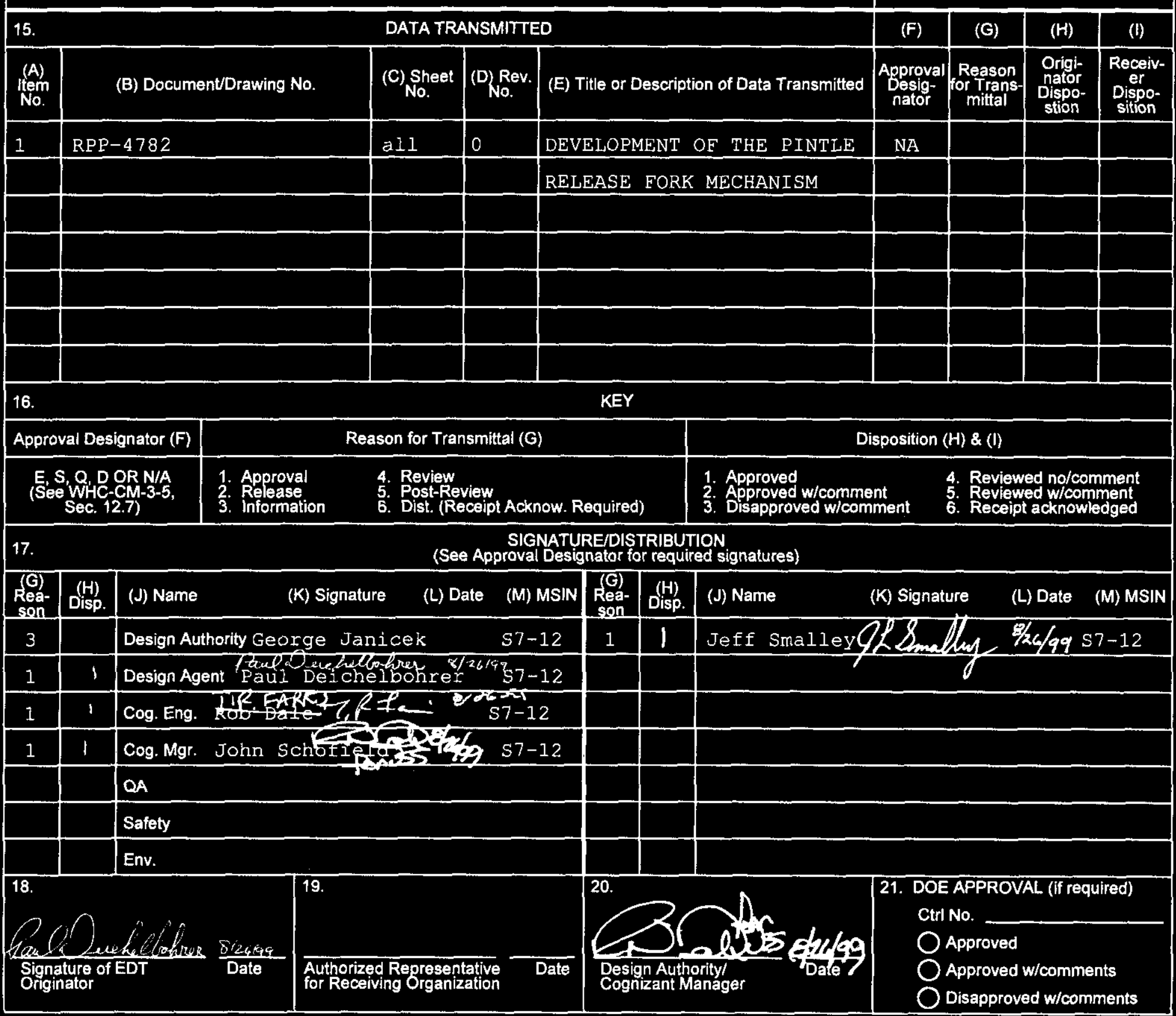




\title{
DEVELOPMENT OF THE PINTLE RELEASE FORK MECHANISM
}

\section{R.M. . Boger}

Prepared by Lockheed Martin Hanford Corporation

Richland, WA 99352

U.S. Department of Energy Contract DE-AC06-96RL13200

\author{
EDT/ECN: 623405 \\ Org Code: UH31000000 \\ B\&R Code: EW3120074 \\ UC: 2030 \\ Charge Code: 102250EI00 \\ Total Pages: 23
}

Key Words: Universal Sampler, Release Disk, Balls, Fork

\begin{abstract}
:
An improved method of attachment of the pintle to the piston in the univeral sampler is being developed. The mechanism utilizes a forked release disk which captures two balls in a cavity formed by a hole in the piston and a groove in the pintle rod.
\end{abstract}

TRADEMARK DISCLAIMER. Reference herein to any specific commercial product, process, or service by trade name, trademark, manufacturer, or otherwise, does not necessarily constitute or imply its endorsement, recommendation, or favoring by the United States Government or any agency thereof or its contractors or subcontractors.

Printed in the United States of America. To obtain copies of this document, contact: Document Control Services, P.O. Box 950, Mailstop H6-08, Richland WA 99352, Phone (509) 372-2420; Fax (509) 376-4989.
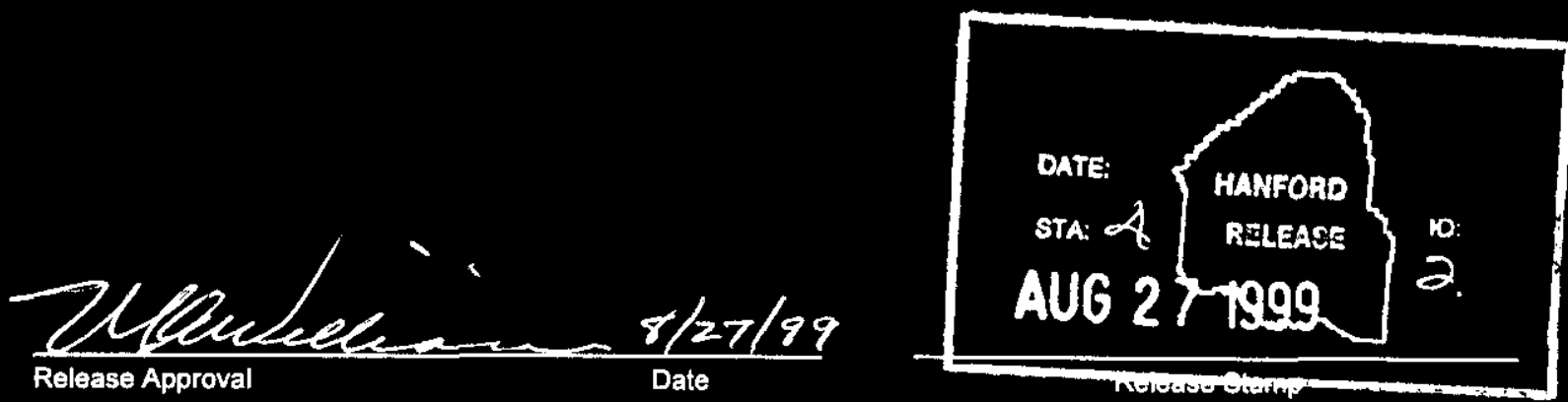

Approved For Public Release 
RPP-4782, Rev. 0

\section{DEVELOPMENT OF THE PINTLE}

RELEASE FORK MECHANISM

\section{Prepared by}

P. R. Deichelbohrer

Numatec Hanford Corporation

For the

Lockheed Martin Hanford Corporation

Richland, Washington

August 1999 
Contents

1.0 PISTON-PINTLE OPERATION

1.1 PERFORMANCE

1.2 CURRENT DESIGN

1.3 OFF-NORMAL PERFORMANCE

1.3.1 Too Tight/Loose

1.3.2 Causal Factors

1.3.3 Fix

2.0 SCOPE

2.1 OBJECTIVE

3.0 DESCRIPTION

3.1 PHYSICAL DESCRIPTION

3.2 VERIFICATION

3.2.1 Size of the Ball

3.2.2 Dimensions of the Weakening Groove

3.2.3 Spring Selection

3.2.4 Length of the Tines

3.2.5 Location of the Hole

3.3 ENGINEERING TASKS

3.3.1 Development Starting Point

3.4 MANUFACTURING

3.5 REVIEW OF ALTERNATIVE TO CURRENT DESIGN 11

3.5.1 Pullout Mode Performance

3.6 PRE-OPERATIONAL TESTS

14

3.6.1 In-Sampler Performance

14

3.6.2 Hot Cell Performance

4.0 ORGANIZATION

5.0 COST

6.0 SCHEDULE

\begin{tabular}{ll}
7.0 & QUALITY ASSURANCE \\
\hline
\end{tabular}

8.0 SAFETY 


\subsection{PISTON-PINTLE OPERATION}

\subsection{PERFORMANCE}

In the universal sampler (H-2-690140) the piston is connected to a pintle rod which pulls it up during filling of the sampler. At the end of the filling stroke the pintle has to be detached from the piston to allow handling equipment (e.g., the remote latch unit) to access the top of the sampler.

\subsection{CURRENT DESIGN}

In the current design, the pintle rod is connected to the piston by means of a sheet metal retaining ring. The ring is press-fit to the end of the pintle. The surface of the piston that engages the retaining ring interfaces with the outer edge of the ring. In this way force between the piston and the pintle deforms the ring (slightly) so that it bites into the rod--holding fast.

To release the piston a release disk (slipped over the pintle--above the piston)engages stops at the end of the stroke. The bottom of the release disk, shaped as a knife edge, transfers the force from the retaining ring's periphery to its interface/intersection with the pintle rod. Applied at the interface/intersection, the knife edge tends to pry the retaining ring from the pintle and, thus, release the piston.

Required performance of the piston-pintle connection shall hold 120 pounds, minimum shall release below 70 pounds (actuation with release disk) shall fail (emergency pullout) below 200 pounds.

The piston-pintle holding force requirement must be at least 120 pounds so that the piston doesn't come loose under the action of the hydrostatic head forces experienced during sampler changeout.

The fail force must not be greater than 200 pounds, because, if the piston were to get stuck in the sampler below the spring stops, the core sample truck draw works would have to force the pintle out of the piston. Forcing it out with more than 200 pounds could damage the core sample truck draw works.

\subsection{OFF-NORMAL PERFORMANCE}

\subsubsection{Too Tight/Loose}

The retaining ring design has been in use since 1996. But early in fiscal year (FY) 1999 the piston-pintle connection of a retained gas sampler (RGS)was reported to have failed. The retaining ring apparently did not release at the end of the stroke. (The failure occurred in a drill string in a waste tank, and failure analysis is difficult because of radiological constraints.) 
It was observed that during the manufacture of RGS samplers (H-2-821608), the end of the pintle rod is annealed to increase the holding capacity of the retaining ring mechanism. Non-RGS samplers, i.e., Universal Samplers, are manufactured without annealing the pintle rod.

Subsequent investigation of samplers on hand (Universal Samplers) revealed that a large fraction of the pistons became detached from the pintles with a small amount of force (estimated to be less than 1 pound).

In a number of subsequent tests it was observed that annealed pintle rods held on to the retaining ring too tightly. With the release disk, forces above 200 pounds were observed. Without the release disk, forces above 1200 pounds could occur.

Pintle rods without heat treatment released the piston too easily. Without the release disk, many released at under 100 pounds. With the release disk "no holding at all" was common.

\subsubsection{Causal Factors}

\subsubsection{Pintle Rod}

Hardness testing of the pintle rod material and of samples of old material suggest that the final heat treatment of the latest-build rod material was different (harder) than that used in retaining ring testing in 1996 (see Paragraph 1.3.1).

\subsubsection{Release Disk}

A number of attempts to associate these failures with the retaining ring itself have not been fruitful. In communication with the ring factory (Eaton Industries) their applications service suggests that the ring was not designed to be used in a "hold and remove" application. The ring was intended to be put on and left on. (Eaton actually suggested that the behavior observed with the RGS is the way they intended it to work.)

Samples of failed rings were sent to Eaton, who found nothing wrong with them. On-site, a study of superficial hardness suggests that the ring hardness varied over a great range. And, the hardness' association with piston-pintle failure has not been established.

\subsubsection{Creep}

It has been postulated that the interference fit between the retaining ring and the pintle relaxes over time, for example, by means of metal creep. In this way, piston-pintle connections tested to 100 pounds holding force when the sampler was fabricated could prematurely release after some time in storage.

At present, however, this creep concept contains some speculation. For example, the failure rate has not been observed to increase with time in storage.

\subsubsection{Fix}

Samples of pintle rod material were sent to Beaver Heat Treating, Portland, OR. Beaver provided samples of rod with a variety of heat treating schedules. Testing of the samples on the SATEC Systems (SATEC) machine in $305 / 300$ revealed that heat treatment of $1100^{\circ} \pm 50^{\circ} \mathrm{F}$ for $3 \pm .3$ hours provided pintle rods with the most satisfactory performance. These pintle rods hold 
and release per specification (see Paragraph 1.1), but not all of the tested specimens met the "fail" criteria. In an emergency, some pulled out at greater than 200 pounds.

The universal sampler drawing has been changed (ECN 651162) to require heat treating (and not annealing) of all pintle rods. All new samplers are being built with heat treated pintle rods. All of the samplers in the warehouse have been returned to the shop to be reworked and have their pintle rods heat treated.

\subsection{SCOPE}

Correction of the pintle-piston problem by heat treatment is not optimum.

- Proper performance depends upon maintaining surface hardness of the pintle within a narrow range. To date the heat treatment schedule given in Paragraph 1.3.3 has provided acceptable hold and release forces. But, it is unclear if other parameters such as, for example, pintle chemical composition, release disk properties, assembly techniques, etc. are sufficiently controlled to assure continued successful performance of the pintle-piston connection.

- A certain percentage of the population of piston assemblies would fail the emergency pullout force requirement with excessive force. This presents a small risk, because in the vast majority of sampler operations release of the piston is accomplished by pressing of the release disk against the top stops. In these cases, release occurs at low force (less than 100 pounds). Nevertheless, an optimum design would fail in-spec every time.

- Random occurrences have been reported in which the piston disconnects from the pintle after the sampler has been "aged" for some months. If these instances are related to creep of the metals in the retaining ring/pintle or are of some other origin, their reported occurrence implicates the current fix with questionable reliability.

To provide the River Protection Project (RPP) with reliable samplers, improving the pistonpintle connection design seems to be justified.

\subsection{OBJECTIVE}

To develop a piston-pintle connection based on the concept of a forked release disk. The development includes demonstration of the principle of operation and detailed design supporting the necessary Engineering Change Notices (ECN) for incorporation into the universal sampler design drawing. 


\subsection{DESCRIPTION}

\subsection{PHYSICAL DESCRIPTION}

The forked release disk mechanism to connect the piston to the pintle is illustrated in Figure 1. The top of the piston is drilled out to accept two balls, which also are seated in a groove in the pintle rod. The pintle-piston holding force is derived from the release disk fork, which forces the balls into the groove in the pintle rod. A spring between the top of the piston and the release disk pushes the disk up against a roll pin stuck into the pintle rod. In this position, the fork of the release disk captures the balls in the piston holes and pintle groove.

To release the piston, there are two holes in the release disk fork. They are positioned to allow the balls to move out of the pintle rod groove when the disk is pushed down.

A spring presses the release disk up so the balls are normally captured in the groove before the piston is set free.

When the release disk engages the spring stops in the sampler, continued pulling on the pintle rod by the core sample truck grapple compresses the spring between the release disk and the piston. When the spring compresses sufficiently, balls enter the holes in the release disk and move out of the pintle groove releasing the piston. The force on the pintle rod will nominally be the force needed to compress the spring.

In the stuck-piston scenario (see Paragraph 1.0) the pintle is forced out of the piston while the balls are still in the groove. In this case the tines of the release disk fork will be bent outward because the balls will be prevented from entering the holes.

Bending occurs at the weakening grooves at the top of the tines. The force of withdrawal is controlled by the dimensions of these grooves.

\subsection{VERIFICATION}

Parameters of the design that has to be optimized include the following:

size of the balls

dimensions of the weakening groove

spring selection

length of the tines

location of the holes. 
RPP-4782, Rev. 0
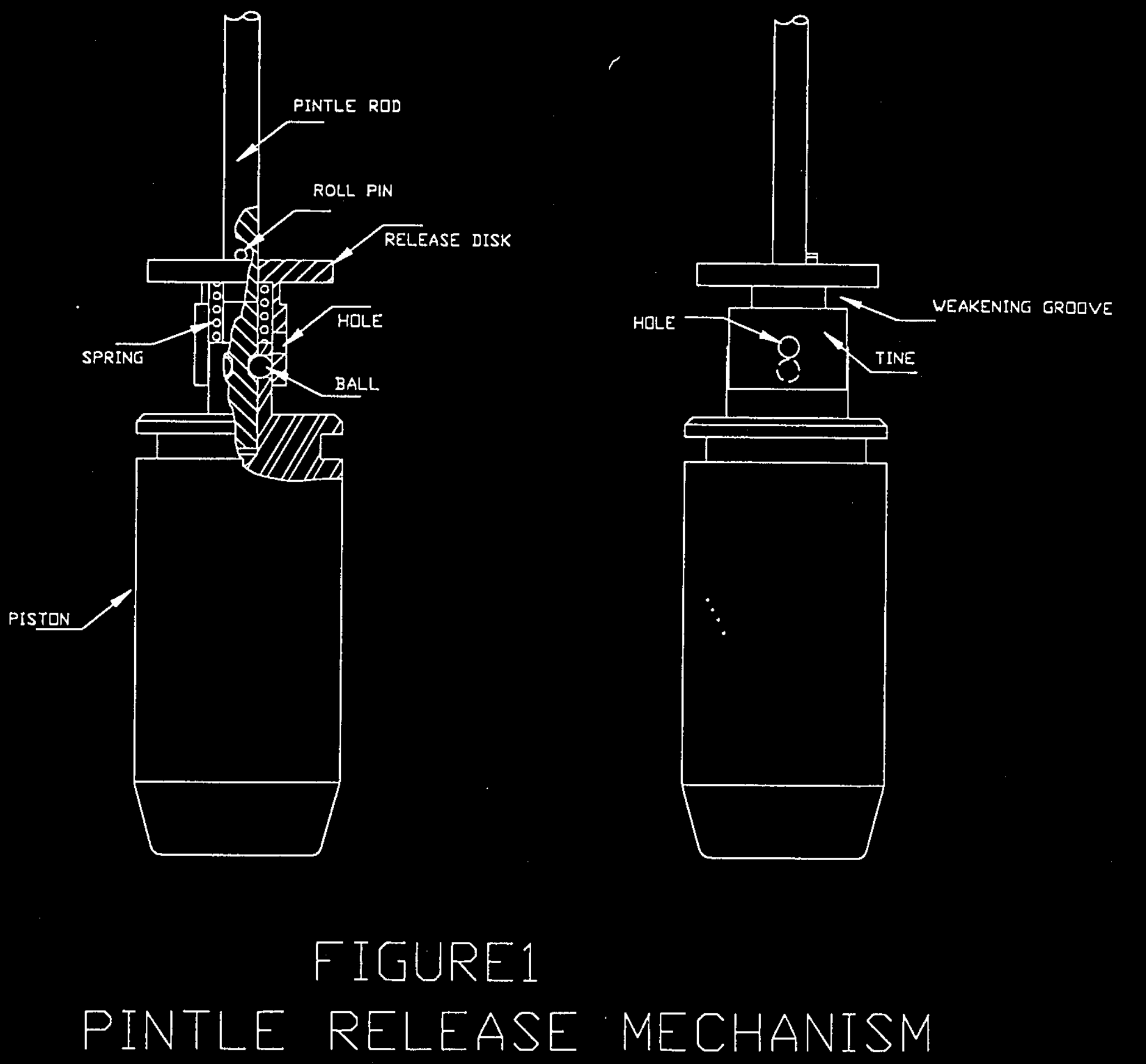

Page 5 


\subsubsection{Size of the Ball}

The ball should be as large as practical. If it is too small, tolerance buildup between the fork and the piston tang could reduce the ball's engagement into the pintle groove and cause premature release of the pintle.

If the ball were too large, the groove in the pintle rod would be too deep, and, consequently, there would be danger that the end of the pintle could break off.

The ball size has to be coordinated with the length of the tines on the release disk. For proper operation the center of the ball must engage the tine well below the hole. If the high point of the ball were within the opening of the hole, the holding force requirement would not be achieved. (Force on the pintle will generate a component of force on the balls, which will pull the release disk downward. This will compress the spring and move the forks to the RELEASE position releasing the piston prematurely.)

Also, it would be convenient if the balls specified were used in some other place in the sampler.

\subsubsection{Dimensions of the Weakening Groove}

In the force-out scenario the release disk remains up, i.e., pressed against the roll pin. The pulling force on the pintle will pass through the balls and into the flat surfaces inside the tines. With sufficient pulling, the tines will bend. But the bending will be plastic. Bending the tines by an amount equal to the depth of the pintle rod groove would be greater than the elastic limit of most metals. (The use of stainless steel is preferred for sampler fabrication.)

In other words, the fork would be permanently bent (out) after the pintle was forced out of the piston.

A certain amount of empirical testing is necessary to determine the correct dimensions of the groove.

\subsubsection{Spring Selection}

The existing sampler design has a release force of approximately 30 pounds. It was desirable to find a commercially manufactured spring that can meet the following criteria:

slip over the pintle rod

- fit between the tines

- have a hard-length force less than 30 pounds

- have a free length consistent with the stroke of the release disk

- be able to push the release disk against the roll pin with non-zero force.

\subsubsection{Length of the Tines}

The overall length of the piston assembly, from the bottom of the roll pin to the bottom of the piston is constrained to be the same as the current design. Also, the distance between the bottom of the roll pin and the top of the O-ring groove is to be maintained. 
This distance is to be made up of

$\checkmark$ release disk thickness

stroke of the spring

$n$ ball diameter

$\checkmark$ hole diameter

seakening groove height.

\subsubsection{Location of the Hole}

The hole location is to be far enough above the ball so that the high point of the ball does not enter the hole without significant compression of the spring. Also, the flat surfaces of the tines that the balls rest against are to be large enough so that tolerance buildup does not allow the ball high point to slip around the bottom of the tines.

\subsection{ENGINEERING TASKS}

\subsubsection{Development Starting Point}

Based upon some preliminary review of alternatives, the following parameters/dimensions are suggested as a first approximation for the attributes of the piston-pintle connection design:

3.3.1.1 Ball Diameter: $1 / 8^{\prime \prime}$ (This ball is currently used in the rotary mode insert bearing.)

3.3.1.2 Spring: SPEC Stock Springs No. C0300-042-00380-M

3.3.1.3 Pintle Groove: .050 deep-chamfered $45^{\circ} .082$ wide at base

3.3.1.4 Material: 304 series stainless steel except the spring, which is music wire.

\subsubsection{Release Disk}

Figure 2 shows the details of the proposed Forked Release Disk.

\subsubsection{Piston}

Figure 3 shows the proposed configuration of the piston to mate with the forked release disk design. 
RPP-4782, Rev. 0
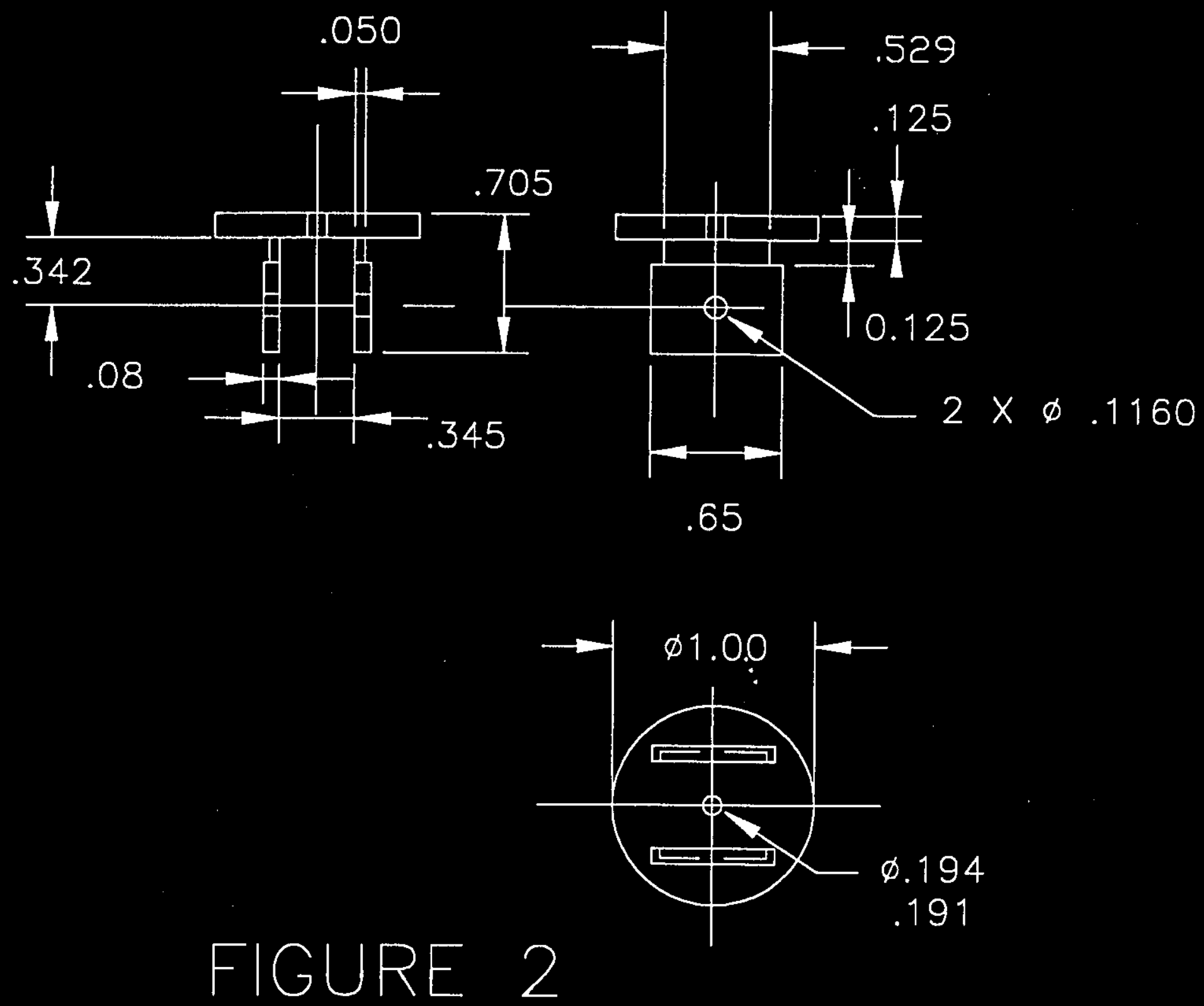

FORKED RELEASE DISK 
RPP-4782, Rev. 0
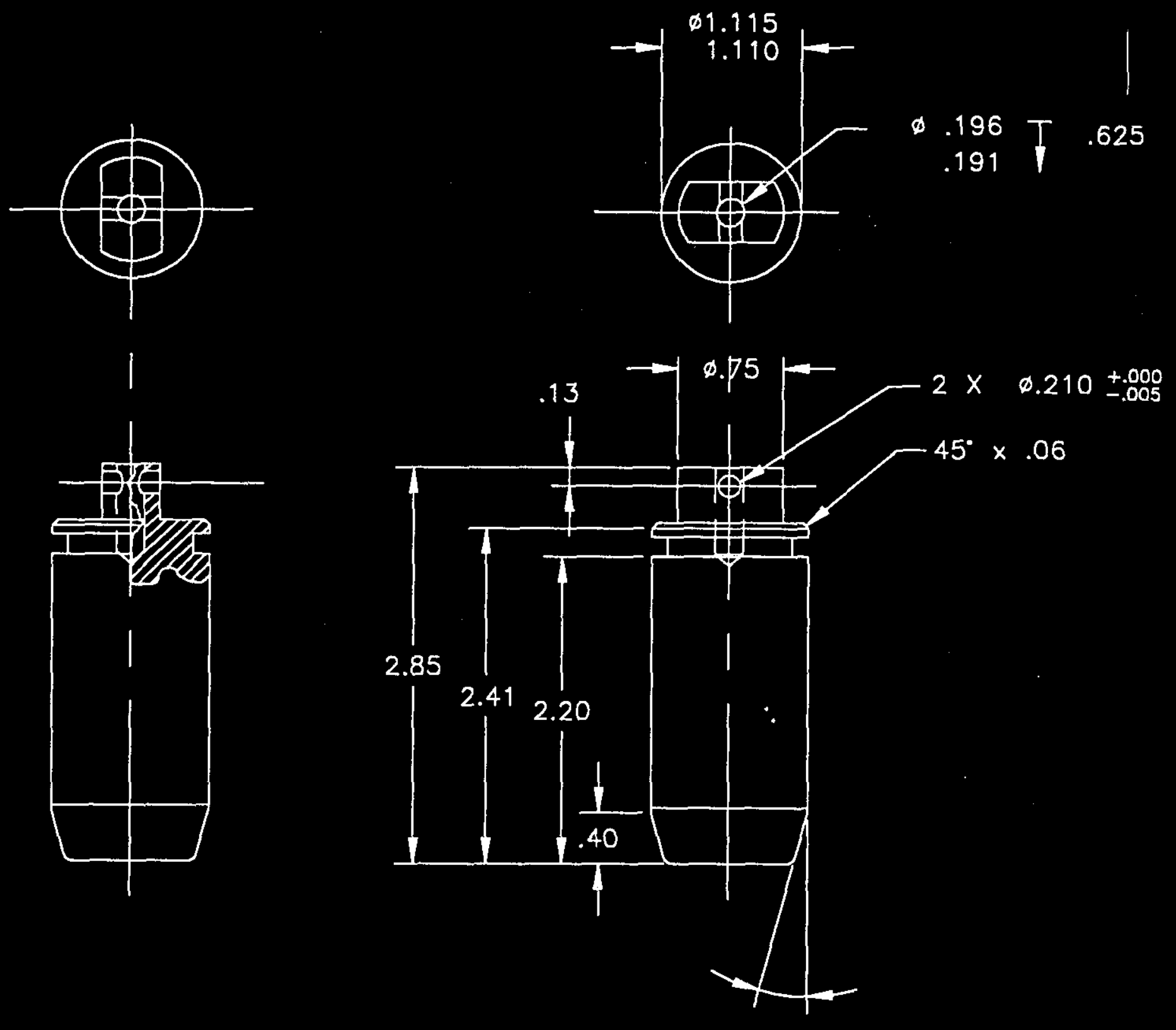

$15^{\circ}$

FIGURE 3

SAMPLER PISTON 


\subsection{MANUFACTURING}

Machining the release disk from a solid bar, the forked release disk mechanism would be more expensive to manufacture than the current design. DynCorp estimates the following man-hours to manufacture a lot of 150 pieces:

$\begin{array}{lccc} & \text { Current } & \text { Forked Release } & \text { \% Increase } \\ & \text { Design } & \text { Disk Design } & \\ \text { Pintle Rod } & 96 & 120 & 25 \\ \text { Release Disk } & 80 & 224 & 128 \\ \text { Piston } & 195 & 223 & 14\end{array}$

The large cost increase for the release disk is due to the labor needed to remove the metal from between the tines of the fork.

To reduce the cost, it is desirable to fabricate the release disk by casting a blank fork structure and then drilling the holes and milling the grooves.

SeaCast, Inc., Marysville, WA, (SeaCast) suggests that the blank could be cast for approximately $\$ 7.50$ each. However, the mold would cost an additional $\$ 4,000$. SeaCast also offers limited production runs by means of stereolithography. With this process there is no mold cost. The price per blank release disk is $\$ 350$. This price is half of the DynCorp price for a single release disk (produced by machining).

Based upon a charge-out rate of $\$ 65 /$ manhour, the cost of manufacturing the fork release disk design, with cast release disk, can be compared with the cost of the old design:

$\begin{array}{lcc} & \text { Current } & \text { Forked Release } \\ & \text { Design } & \text { Disk Design } \\ \text { Pintle Rod } & \$ 6 \mathrm{k} & \$ 8 \mathrm{k} \\ \text { Release Disk } & 5 \mathrm{k} & 3 \mathrm{k} \\ \text { Piston } & 13 \mathrm{k} & 25 \mathrm{k} \\ \text { Total (150 pieces) } & \$ 24 \mathrm{k} & \$ 25 \mathrm{k}\end{array}$

Although the new design is somewhat more complicated than the old one, utilizing casting for the release disk will offset the cost. The two designs are expected to be comparable in price. 


\subsection{REVIEW OF ALTERNATIVE TO CURRENT DESIGN}

\subsubsection{Pullout Mode Performance}

A forked disk pintle release mechanism was fabricated for testing. The set of parts consists of

one piston

one pintle rod

- three release disks (machined)

four release disk blanks (produced by stereolithography and casting)

- two balls and a spring.

The release disks were fabricated with a variety of dimensions for the weakening groove (see below). Normal release of the pintle was confirmed on all of the assemblies to occur at a force of less than 15 pounds.

The emergency pullout force was tested for each of the release disks assemblies and tested in the SATEC machine in 305/300. Designing the weakening groove to obtain the correct value for pullout force absorbs most of the development effort.

\subsubsection{Lower Limit Calculation}

A minimum expected value of the force to pull out the pintle rod can be calculated by considering that the tines will bend as a sort of cantilever beam when the balls are forced out of the pintle groove. The maximum force that the balls can push in with is controlled by the force needed to bend the tines.

Neglecting friction, the $45^{\circ}$ edges of the groove in the pintle rod will convert the inward force from each ball to an equal amount of axial force on the pintle. Therefore, the pullout force will be 2 times the maximum force, $F$, with which a ball can push in. The value of $F$ will depend upon the plastic properties of bending of the tine at its weakening groove.

A lower limit for $\mathrm{F}$ can be estimated by calculating the force needed to deflect a cantilever beam of dimensions similar to the tines.

If the moment of resistance, M (Avallone 1996), is

$\mathrm{M}=\mathrm{SI} / \mathrm{c}$

where: $\mathrm{S}$ is the cold working stress

$\mathrm{I}=\mathrm{wt}^{3} / 12$ is the moment of inertia of the weakening groove section

$w$ is the width of the tine in the weakening groove

$t$ is the thickness in the weakening groove

$\mathrm{c}=\mathrm{t} / 2$.

The moment is figured by multiplying the force, $\mathrm{F}$, with which the ball pushes out times the distance from the top of the groove to the point of contact of the ball (approximately 0.7 in). Combining these expressions

$\mathrm{F}=0.7 \mathrm{Swt}^{2} / 6$ 
This formula neglects friction and approximates the actual stress distribution in the groove and the change in material strength/shape as plastic bending proceeds. The actual pullout force could be significantly higher.

In Avallone 1996 the cold working stress for stainless steel is approximately $200,000 \mathrm{lb} / \mathrm{in}^{2}$, which gives a value of $F$ of approximately 30 pounds if the width is .529 inches and the thickness is .05 inches. (The experimental disks can be readily bent with pliers.)

These considerations suggest that the pullout force would be at least 60 pounds.

\subsubsection{Empirical}

The emergency pullout force of the forked release disk pintle connection was measured with the SATEC machine in the 305/300 Building. Results are shown in Figure 4. Values of pullout force with no weakening groove and different thicknesses of the tines are shown in the graph (force: $300-400$ pounds).

With weakening grooves of .05 inches thickness and different widths, the forces are in the 100-160 pound range (see Figure 4). Cast disk results are shown with hollow circles and machined disk results are shown with "crossed" circles.

The dashed curve in Figure 4 is the lower limit value of the pullout force calculated above. It may be noted that the measured values are substantially higher, which confirms the limitations of the above calculations. 
RPP-4782, Rev. 0

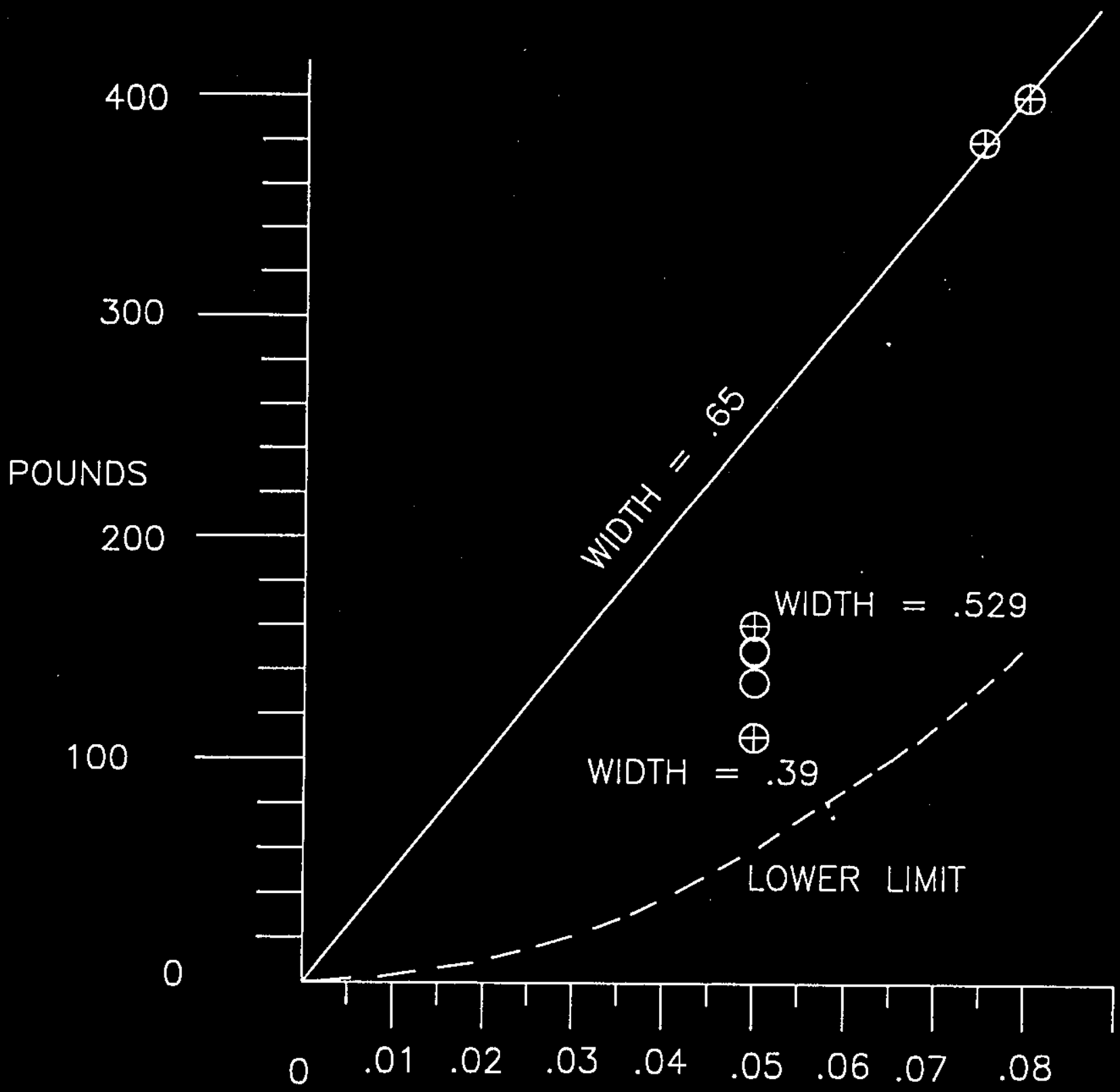

THICKNESS OF TINES OR MATERIAL IN GROOVE $[\mathrm{INCH}]$

FIGURE 4

THICKNESS OF WEAKENING GROOVE vs. PULL-OUT'FORCE

Page 13 
The same, measured data are plotted in Figure 5, which shows how the pullout force varies with the width of the groove. Note that all of the points with thickness of .05 each $(\mathrm{TK}=.05)$ lie on a straight line (essentially). This indicates that the pullout force is proportional to the width of the groove.

The data for $\mathrm{TK}=.05$ are shown in Table 1 . With both machined and cast release disks, a force of approximately 150 pounds occurs for a width of .529 inches.

Table 1

\begin{tabular}{|l|c|c|c|}
\hline & Width (inches) & Pullout Force (pounds) & Comment \\
\hline Machined & .529 & 161 & \\
\hline Cast & .529 & 149 & \\
\hline Cast & .529 & 153 & \\
\hline Cast & .529 & 151 & * Testing Machine \\
\hline Cast & .529 & 135 & \begin{tabular}{l} 
Malfunction \\
\hline
\end{tabular} \\
\hline
\end{tabular}

* During the pull test of the last disk, the chuck in the testing machine released at 135 pounds, but the pintle did not release. When it was re-tested, the pintle released at 133 pounds.

The straight line shown in Figure 4 suggests that the force is roughly proportional to the thickness as well as the width. If a straight line were drawn from the origin and through the group of points for width $=.529$ inches, it would have slope of $150 / .05=3 \mathrm{lb} / \mathrm{mil}$. That is, for each increase in web thickness of 1 mil the pullout force would increase 3 pounds.

To keep the pullout force within a range of \pm 25 pounds, the thickness will have to be held within \pm .008 inch. This will represent the working tolerance for cutting the groove in the blank disks.

\subsection{PRE-OPERATIONAL TESTS}

\subsubsection{In-Sampler Performance}

To develop the forked release disk pintle connection into a reliable system of use in the universal sampler, it will be necessary to demonstrate satisfactory operation on a population of assemblies. To obtain an array of forked release disk pintle connection assemblies, a quantity (100 pieces) of cast release disk blanks will be ordered from SeaCast. In addition, the mold will be built by SeaCast.

These blanks will be machined into completed forked release disks.

Five piston and pintle rods will be fabricated in accordance with the designs given above. The pistons and pintle rods are re-usable.

The completed release disks will be assembled to the pistons/pintle rods--five at a time. They will be installed in a modified sampler, and their release forces will be measured/recorded utilizing the SATEC machine in 305/300. 
RPP-4782, Rev. 0
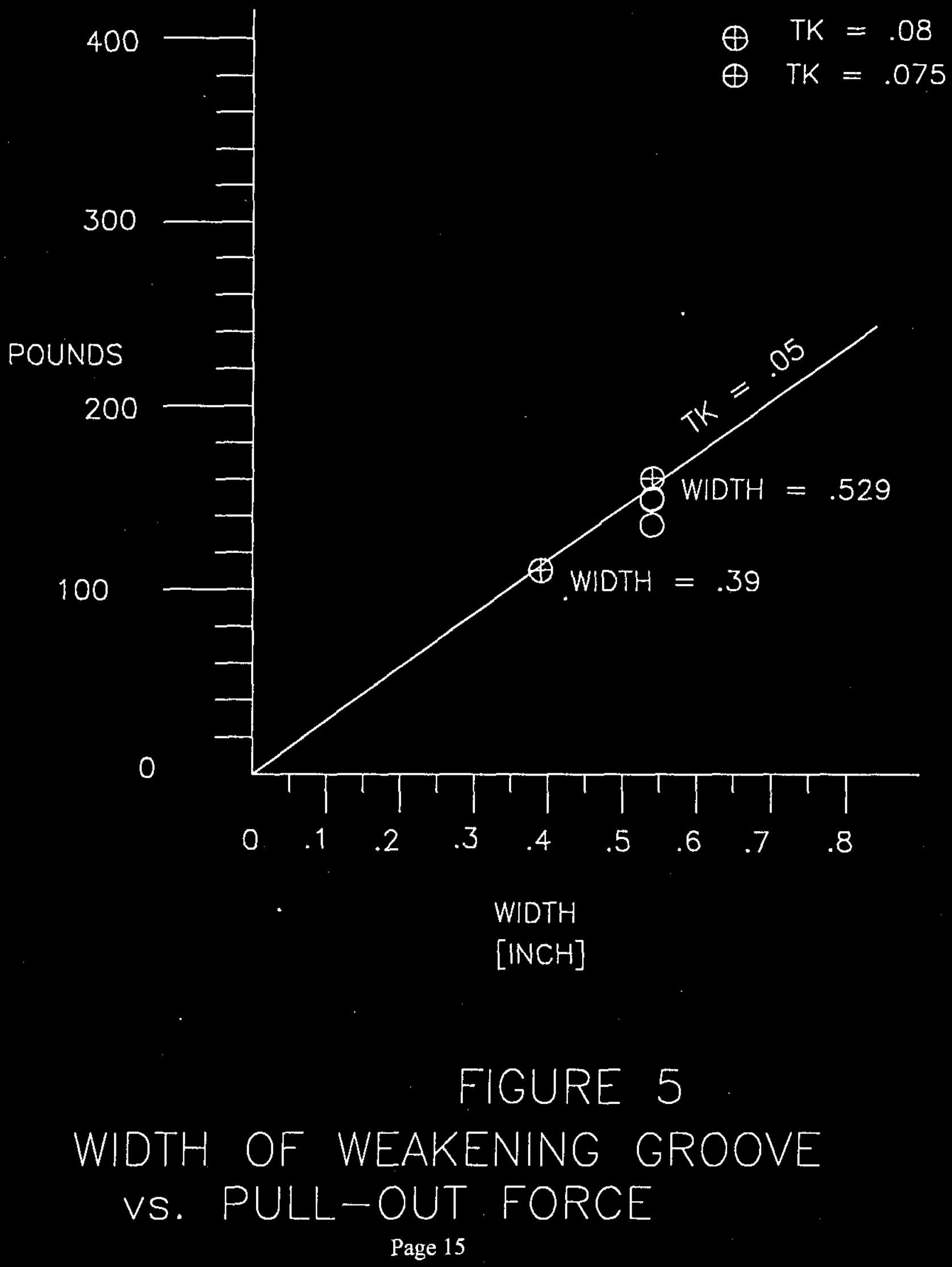
The forked release disk pintle connection will be re-assembled after the release force has been measured. The piston-pintle assembly will be tested for emergency pullout force utilizing the SATEC machine. The emergency force will be read and recorded on the same data sheets as the release force (see Appendix).

The data will be statistically analyzed to estimate the fraction of the forked release disk pintle connection assemblies that will perform outside of the specified requirements.

\subsubsection{Hot Cell Performance}

Six of the piston-pintle assemblies will be assembled into samplers after the piston-pintle connection has been tested to 100 pounds. Three of the samplers will have their valve-closure mechanisms activated by pulling the release disk against the spring stop (normal pintle release mode). The other three will have the pintle forced out of the piston, which will be "stuck" below the spring stops.

The test samplers will be forwarded to the 222-S Laboratory for testing in the hot cell extrusion machinery.

Laboratory technicians will verify that there is a lack of interferences with the extrusion machinery and that the forked-retaining ring components that are expelled after actuation (balls and spring) do not interfere with $222-\mathrm{S}$ operations.

\subsection{ORGANIZATION}

Cognizant Engineer: Robert N. Dale

Cognizant Engineering Manager: John S. Schofield

Design Authority: George P. Janicek 
RPP-4782, Rev. 0

\subsection{COST}

$\begin{array}{ccc}\text { Material } & \text { Labor } & \text { Total } \\ (\$ \mathrm{k}) & (\$ \mathrm{k}) & (\$ \mathrm{k})\end{array}$

$\begin{array}{lllr}\text { mold } & 4.000 & & 4.000 \\ \text { blanks } & 1.000 & & 1.000 \\ \text { final machining } & & 1.0 & 1.000 \\ \text { pistons } & 0.100 & 0.5 & 0.150 \\ \text { pintle rods } & 0.050 & 0.5 & 0.550 \\ \text { springs } & 0.020 & & 0.020 \\ \text { balls } & 0.005 & & 0.005 \\ \text { assembly } & & 1.0 & 1.000 \\ \text { modified sampler } & & 1.0 & 1.000 \\ \text { test samplers } & & & 10.000 \\ \text { 222-S service } & & 2.0 & 5.000 \\ \text { release force testing } & & 5.0 & 5.000 \\ \text { pullout force testing } & & 5.0 & 3.000 \\ \text { final Report } & 3.0 & 34.000\end{array}$

\subsection{SCHEDULE}

Order mold and blanks

\begin{tabular}{cl}
$\underset{\text { Begin }}{11 / 07 / 99}$ & \multicolumn{1}{c}{ End } \\
$10 / 28 / 99$ & $11 / 4 / 99$ \\
$10 / 30 / 99$ & $11 / 21 / 99$ \\
$12 / 05 / 99$ & $01 / 08 / 00$ \\
$01 / 16 / 00$ & $03 / 25 / 00$ \\
$01 / 20 / 00$ & $03 / 25 / 00$ \\
$01 / 20 / 00$ & $03 / 25 / 00$ \\
$11 / 01 / 99$ & $03 / 25 / 00$ \\
& $04 / 15 / 00$
\end{tabular}

\subsection{QUALITY ASSURANCE}

The forked release disk pintle connection design is intended to be included as an option in the universal sampler design. This drawing is a baseline document.

The Design Authority is George P. Janicek. 


\subsection{SAFETY}

The universal sampler is a safety class item. However, only the material composition of certain external parts (quadralatch, inner race) is significant to the safety class rating. The piston-pintle connection is completely inside of the sampler and does not affect the sampler's safety class rating.

\subsection{REFERENCE}

Avallone, Eugene A., and Theodore Baumeister III, 1996, Marks' Standard Handbook for Mechanical Engineers, pp. 5-21, McGraw Hill, Boston, Massachusetts. 
RPP-4782, Rev. 0

\section{APPENDIX}

DATA SHEETS FORKED RELEASE DISK

PISTON-PINTLE CONNECTION

Page 19 
RPP-4782, Rev. 0

Hot Cell Performance

\begin{tabular}{|c|c|c|c|c|}
\hline $\begin{array}{c}\text { Disk } \\
\text { Number }\end{array}$ & $\begin{array}{c}\text { Holding } \\
\text { Force }\end{array}$ & $\begin{array}{c}\text { Release } \\
\text { Force }\end{array}$ & $\begin{array}{c}\text { Release } \\
\text { Mode }\end{array}$ & 222-S Lab Comments \\
\hline 1 & & & & \\
\hline 2 & & & & \\
\hline 3 & & & & \\
\hline 4 & & & & \\
\hline 5 & & & & \\
\hline 6 & & & \\
\hline
\end{tabular}

Pull Out Force Testing

\begin{tabular}{|c|c|c|c|c|c|}
\hline $\begin{array}{c}\text { Disk } \\
\text { Number }\end{array}$ & Release Force & Pullout Force & $\begin{array}{c}\text { Disk } \\
\text { Number }\end{array}$ & Release Force & Pullout Force \\
\hline 7 & & & 36 & & \\
\hline 8 & & & 37 & & \\
\hline 9 & & & 38 & & \\
\hline$\overline{10}$ & & & 39 & & \\
\hline 11 & & & 40 & & \\
\hline 12 & & & $\overline{41}$ & & \\
\hline 13 & & & 42 & & \\
\hline 14 & & & 43 & & \\
\hline 15 & & & 44 & & \\
\hline 16 & & & 45 & & \\
\hline 17 & & & 46 & & \\
\hline 18 & & & 47 & & \\
\hline 19 & & & 48 & & \\
\hline 20 & & & 49 & & \\
\hline 21 & & & 50 & & \\
\hline 22 & & & 51 & & \\
\hline 23 & & & 52 & & \\
\hline$\overline{24}$ & & & 53 & & \\
\hline 25 & & & 54 & & \\
\hline 26 & & & 55 & & \\
\hline 27 & & & 56 & & \\
\hline 28 & & & 57 & & \\
\hline 29 & & & 58 & & \\
\hline 30 & & & 59 & & \\
\hline 31 & & & 60 & 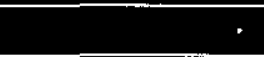 & \\
\hline 32 & & & 61 & & \\
\hline 33 & & & 62 & & \\
\hline 34 & & & 63 & & \\
\hline 35 & & & 64 & & \\
\hline
\end{tabular}

